\title{
NIGERIAN CULTURAL HERITAGE: PRESERVATION, CHALLENGES AND PROSPECTS
}

\author{
Blessing Nonye Onyima* \\ http://dx.doi.org/10.4314/og.v12i 1.15
}

\begin{abstract}
Nigerian is a country endowed with a lot of cultural heritages sourced from its multicultural communities. Contemporary status of most Nigerian cultural heritages (both material and non-material) is best described as endangered. This paper derives from a functionalist perspective which descriptively presents a historical, anthropological, and archaeological account of the Nigerian cultural heritage. Efforts at preserving these heritages are obstructed with daunting challenges, particularly human activities such as trafficking and exportation of Nigerian arts, thefts and looting of museums, vandalism, iconoclasm, Christianity, civilization, commerce, change, and developmental projects among others. Hence, the clarion call for its preservation due to avalanche of prospects derived from an adequately preserved cultural heritage.
\end{abstract}

\section{Introduction}

Globally the importance of heritages to countries and even in developing nations like Nigeria cannot be over-emphasized. This is due to its economic, historical, tourist, aesthetic, educational and research significance. For a critical and comprehensive understanding of Nigerian Cultural heritages, the approach adopted in this chapter is anthropological, archaeological, and historical and the pattern of presentation is purely descriptive. Heritages are cherished characteristic features of a society passed down from generation to generation through conscious preservation. Heritages refer to the riches of extinct and extant societies which are of historic, educational, recreational, and economic importance, preserved and handed over from one generation to another. Put differently, heritages are significant endowments emanating from man and nature. Following from the above, heritages could be categorized into two, based on their sources namely: ecological/natural heritages and cultural heritages. Nigeria is 
endowed with both types of heritages. "Nigeria is a country located in the Eastern part of West Africa", (Aremu, 2008, p. 175). Geographically Nigeria occupies a space of 923,768 square km. It is the most populated (over 140 million based on the 2006 census figures) multi-ethnic and multi-lingual country in Africa, with over 250 ethnic groups. It has the Igbo to East, the Yoruba to the West and the Hausa-Fulani to the North as major ethnic groups among other perceived 'minor' ethnic groups. Ecological or natural heritages emanate from nature and environment. Ecological heritages can be defined as the relatively undisturbed or uncontaminated natural areas with its wild plants (flora) and animals (fauna) and its geomorphic features (caves, rivers, lakes, hills, mountains, cataracts) conserved for the specific objectives of studying, admiring, and enjoying the scenery which it affords (Duke in Aremu, 2008; Eluyemi, 2002). Nigeria is endowed with 'about 29 game reserves, 1129 forest reserves, 4 game sanctuaries, 2 strict nature reserves and 8 national parks' (Marguba, 2008, p. 37). It is pertinent to state that ecological heritage is outside the scope of this paper, therefore we are going to concentrate on the second type of heritage mentioned above which is cultural heritage. Cultural heritage is the legacy of physical artifacts and intangible attributes of a group or society that are inherited from past generations, maintained in the present and bestowed for the benefit of future generations(http://en.wikipedia.org/wiki/Cultural_heritage). Cultural heritages evolve from man's ingenious activities, preserved and transmitted through oral traditions or in written concrete forms across generations of human societies.

Oral tradition is the body of information concerning history, culture and environment of a people at any given time and space. This information is often obtained through the words of mouth. It is also a set of verbally transmitted pieces of information about the experiences and worldviews of a people. These experiences and worldviews are preserved in the memories of the group of people and are transmitted from one generation to another (Ogundele, 2000, p.14). 
Oral tradition remains an indispensable cultural heritage management strategy among pre-modern and pre-historic Africans which continues to be relevant in contemporary Nigeria. Most oral traditions obtained through ethnographic studies have been confirmed by archaeological and historical findings (Fasuyi, 1973). The clan \& village heads, kings, chiefs, deity priests, aged/older men and women serve as repositories and custodians of their oral traditions. They include traditional proverbs, tales/dance by moon lights (known as akukoifo/egwuonwa among the Igbo of eastern Nigeria), adages, lullabies, poems, riddles, incantations, praise songs such as oriki, recitals of traditional religions like the Ifa verses among the Yoruba of western Nigeria and other facets of their individual community's cultural heritages. Oral tradition has proved to be a useful instrument to professionals like the archaeologists and ethnographers in locating and identifying cultural heritage sites/areas for further studies and preservation. Cultural heritage is, however limited to man-made artifacts and ideologies (Eluyemi, 2002). Cultural heritages can be defined as the sum total of the people's cherished arts, customs, festivals, sacred or worship sites, norms, values, ideologies, dress and dress-patterns, traditional monuments $\&$ architectures, technology and technological sites and other artifacts which are cherished and conserved for their historical, political, educational, recreational and religious significance among others. Cultural heritages are therefore the sum total of material and non-material cultures of a particular society transmitted across generations.

\section{Theoretical Explanations}

The need to preserve Nigerian cultural heritage is best explained through the functionalist perspective as enunciated by Bronislaw Malinowski (1884-1942). Functionalist emphasize that society consist of inter related parts which work for the integration and stability of the whole system. Malinowski's functionalism assumes that all cultural traits are useful parts of the society they occur, in other words; all customary patterns of behavior, belief attitudes, and 
social structures perform a function within the society they occur. He emphasizes that social structures and social institutions exist in societies to meet or perform psychological and biological needs for the people. It provides cohesion in the social order by promoting a sense of belonging and collective consciousness, a point fervently argues by Emile Durkheim 1897. Preservation of Nigerian cultural heritages is capable of promoting collective consciousness in terms of unity, oneness, nationalism and fostering peaceful co-existence among Nigerians. For instance, cultural heritages can be categorized into two namely material/tangible and non-material/intangible cultural heritages. This is because culture in itself is "both physical and non-physical in character" (Ogundele 2000, p. 12).

Tangible cultural heritages include man's physical ingenious products which can be touched and seen such as architecture/buildings, defensive walls and ditches, crafts, tools, ivory, cowries, paintings, textiles, pestles, mortars, iron furnaces, knives, food, wooden objects, tombs \& grave goods, temples, dresses, pottery \& potsherd pavements, monuments, books, works of art, and among other artifacts. "Artifacts as a broad concept are objects and/or features made and/or used by man/humans in an attempt to cope with the challenges and problems of social and natural conditions. It is therefore important to state that man cannot survive without the construction and use of artifacts" (Ogundele, 2014 , p.5). This further gives a deeper explanation to the function of cultural heritages to society. On the other hand, non-material or ideological cultural heritages include all intangible and invisible aspects of a peoples' ways of life such as ideas, folklore, kinship, norms, values, worldviews, philosophies of life, religious beliefs and practices, music, dance, festivals, traditions, language, and knowledge among others (Nnonyelu, 2009; Ogundele, 2000).

The above enumerations show the complexity of cultural heritages, but for simplistic purposes they could also be classified as moveable (artifacts) and immoveable cultural heritages (monuments) based on their nature of portability which requires different specialized skills for their preservation. It is however pertinent to 
stress that most of these Nigerian cultural heritages are threatened due to faulty efforts at preserving and conserving them. For instance, in south eastern Nigeria, the current status of the following cultural heritages should best be described as "endangered": Ikoro (slit drum) is a traditional medium of communication. Oriko- a traditional practice of re-integration among the Igbo through which social deviants are welcomed back to society after punishment such ostracism. Iru-mgbede- an Igbo traditional indigenous educational institution through which young maidens are initiated into womanhood (Mathias \& David, 2014). There are a host of other cultural heritages among communities in Nigeria that are under threat of extinction. There is therefore a need for a conscious preservation of some useful Nigerian cultural heritages, while negative ones should be discarded.

\section{Historical Dimensions to the Preservation of Nigerian Cultural Heritages}

Nigeria is distinguished in sub-Saharan Africa because of her "rich manifestations of vast cultural heritages" of the past (Sowunmi, 2008, p.77). Most of the artifacts and collections from remarkable culture areas in Nigeria are displayed in museums and galleries all over the world. This is because they were consciously preserved. Preservation has been defined by Eluyemi, (2002, p.2) as "the promotion of cultural property whether of concrete or non-concrete nature, past or present, written or unwritten/oral. He further posits that preservation involves the identification, documentation (appropriate registration) and proper storage of cultural objects whether in private hands or in museums. The preservation of Nigerian cultural heritages is arguably threatened by human activities, natural forces, biological and chemical agents among others (Ogundele, 2014, Okpoko, 2011). However, the little successes made over the years in the preservation of Nigerian cultural heritages has been attributed to conscious systematic and scientific efforts, and researches conducted by professionals in the disciplines of archaeology, cultural anthropology, linguistics, 
ethnography, palynology, paleontology, geology, geography, museum studies, among other cultural resource managers (Ogundele, 2014; Onwuka, 2002; Andah, Okpoko \& Folorunso 1993; Okpoko, 2011).

Preservation is very vital because of its capacity to promote the past ways of life that are useful to contemporary societies. Arguably, the past is essentially the key to the present and platform into the future. An understanding of the preservation of Nigerian cultural heritages can best be described in three dimensions namely the pre-colonial, colonial and post-colonial. Nigerian cultural heritages during the pre-colonial era were preserved in royal palaces of tribal kingdoms and empires by kings, heads of families and kindred, deity priests in charge of shrines and sacred grooves among others (Fasuyi, 1973). The cultural activities, arts and festivals were managed by the traditional rulers and chiefs in council through delegation of powers to talented specialist. For instance, the carvers made masks for masquerades, the traditional costume designers made royal regalia, beads and dresses, other crafts makers made baskets, local talking drums and other musical instruments; the music and dance specialists made music, praise songs to celebrate valiant warriors and trained dancers for annual festivals. These skills were preserved through oral tradition and training of this crafts men and women; and then the skills were handed over from generation to generations. This generational pattern of preserving Nigerian cultural heritages was completely or partially truncated in most parts of Nigeria due to unsolicited incursion of colonialism.

Colonialism ushered in an era of unrestricted negative human activities such looting, vandalism, thefts, unscientific excavation of grave goods, iconoclasm, wars, illicit trafficking of cultural objects among others. The period 1900 to 1960 marked the era of colonization in Nigeria (Fasuyi, 173). The most remarkable of these destructive human activities on Nigerian cultural heritage occurred during the punitive expedition in 1897 when the British colonial administration attacked the Benin culture area, looted the rich bronze works and art treasures of the Benin royal palace and 
exiled the King to Calabar where he later died in 1914 (Eluyemi, 2002; Aremu, 2008; Fasuyi, 1973). Colonialism thus, waned the influence of traditional rulers and their role in preserving Nigerian cultural heritages. For instance, during the colonial period western educational systems were introduced to replace traditional educational systems such as Irumgbede among the Igbo. In schools, English language and foreign literatures were taught and read at the detriment of Nigerian indigenous languages (Fasuyi, 1973).

The current status of Nigerian indigenous linguistic heritages is best described as endangered and they are arguably almost at the verge of extinction. Also Missionaries introduced Christianity which relegated and designated Nigerian traditional religions as idol worship and branded practitioners as heathen and unbelievers (Eluyemi, 2002). In the entertainment industry, the traditional poets, praise-singers, clowns, comedians, dramatists, in the king's courts, traditional dance and dancers, songs, music, and local costumes, musical instruments such as drums have been replaced with western music, foreign dance styles, foreign dress and dress patterns, western musical instrument such as bands, microphones, guitars, pianos, etc. All these mindless replacements continued without Nigerians knowing its implications until a few expatriated sensed the need to preserve Nigerian cultural heritages during the colonial era (Eluyemi, 2002; Fasuyi 1973). These foreigners advised the then colonial government on the need to preserve Nigerian cultural heritages, they suggested that museums should be created, also Nigerian arts, cultures and history should be taught in schools. For instance, E.H. Duckworth wrote in 1937,

Help to build up an appreciation of old things; do not be afraid of them. Respect the past, record its history, treasure its sign posts, and help to build museums in Nigeria. The day may come when people will voyage from all parts of the world to see the museums and exhibition rooms in Lagos, Abeokuta, Ife and Benin City (Fasuyi, 1973 p. 24). 
Another expatriate known as K.C. Murray on the other hand also made this suggestion; "Make a list of all works of art and gather them whenever possible into the safety of museum" (Eluyemi, 2002 p.6). "E.H. Duckworth who was the editor of the colonial government owned Nigerian magazine, this magazine was first published in Nigeria in 1923 as the Nigerian Teacher, its title latter changed to Nigeria in 1927 and later became the federal government cultural information journal" (Fasuyi, 1973 p. 23). Also other British colonial civil servants such as K.C. Murray who was an art teacher, B. E. Bernard Fagg, and S. Milburn among others also made contributions for the preservation of Nigerian cultural heritages (Eluyemi, 2002). "One result of wanton exportation of Nigerian antiquities was the emergence of museum creation in Nigeria, creation of Nigerian Antiquity Service in 1943 and the Office of the Surveyor of Antiquities in the same year" (Eluyemi, 2002 p.6). Systematic preservation of cultural heritages therefore gradually began with suggestions by colonialists and finally metamorphosed into a well formulated cultural policy in 1988 which necessitated the creation of museums.

A museum is an institution that collects, studies, exhibits, and conserves artifacts or objects for cultural and educational purposes (Okpoko, 2011). According to Eluyemi, (2002 p.7) "the first museum in Nigeria was created in 1945 at Essie known as Ileere (house of images)", followed by other museums such as Jos museum in 1954 (Fasuyi, 1973 wrote Jos museum was opened in 1952), Ife museum built in 1954, Lagos museum in 1957, Owo museum in 1958, Benin museum in 1959 and Kano museum in 1960 among all others. In summary, preservation of Nigerian cultural heritages during the colonial era is remarkable that some commendable land mark achievements were made such as the creation of the "Nigerian magazine, establishment of museums of antiquities, the creation of the post of the federal art adviser, the creation of the department of art" (Fasuyi, 1973 p.23).

In the post colonial period, the Nigerian Antiquity Service metamorphosed into what is now known as National commission for 
Museums and Monuments (NCMM). Museums are currently managed under the National commission for museums and monuments (NCMM), with its administrative headquarters at Abuja but the national museum at Onikan, Lagos used to be the headquarters of NCMM. The Onikan museum houses the collections and exhibition of archaeological discoveries and documents of our recent pasts. There are 3 main galleries in the Onikan museum - One housing Benin arts, another on treasurers of ancient Nigeria and a third one on contemporary Nigeria. There is a museum kitchen and theatre for staging plays, recitals and cultural festivals (Aremu, 2008). According to Okpoko (2011:1) "Museums are institutions for research, teaching, exhibition and conservation in one or more fields of human activity". It is an institution that collects, studies, exhibits and conserves objects for cultural and educational purposes.Nigerian museums are part of Nigerian historic and cultural heritage and are found in almost all states of contemporary Nigeria. Apart from national and state museums, Nigeria has lots of other types of museums such as privately owned museums like the obuofonri, Igbo-ukwu museum and odinaani museums all at Anambra state, University museums, war museum at Umuahia, medical or anatomy museum in Jos, among others.

\section{Ethnographic and Ethnological Description of the Peoples and Selected Cultural Heritages in Nigeria}

It is very important to describe the people of Nigeria before highlighting some of their cultural heritages which are often gotten through ethnographic studies. Ethnography is the systematic and scientific investigation of the ways of life of a people. Kottack, (2004:10) defines Ethnography as "the account of a particular community, society or culture". Ethnology on the other hand, is the comparative analysis of cross-cultural accounts. This is in order to identify similarities and differences as well as ascertain changes and developments that have taken place across various Nigerian cultures over time and space. Kottack, (2004:10) also defines ethnology as "the examination, interpretation, analysis and comparison of the 
results of ethnography. That is, the data gathered through ethnography from different societies are comparatively analyzed through ethnology in order to make generalizations about society and culture.

Following from the above background, through ethnographic studies, Aremu (2008:177) posits that Nigeria is a multi - ethnic country with three major ethnic groups, the Igbo to the east, the Yoruba to the west and the Hausa - Fulani to the North. He further asserts that there are about 250 other ethnic groups in the country. However, Ezeh (2002:102) ethnologically argues that "no one extant published source has an accurate number of the cluster of Nigerian ethnic groups". To him, at best such sources contain figures that may serve as clues for further inquires. Ezeh (2002:102) further reveals "that Meek, (1931:23) found 255 ethnic groups in the entire northern Nigeria alone, but Bleambo, (1990:187) cited 250 for the entire nation - state". He points that this ethnographer followed a method that distinguished language groups from ethnic groups which resulted at the conclusion that the Nigerian language groups are 394".

Put differently, the fact here is that attaching a definite number to the ethnic groups in Nigeria is a herculean task due to the complex multi-ethnic, multi-tribal and multi-linguistic nature of its populace. This has been traced by different scholars as the disruption and confusion that resulted due to colonial/European contact and their undue lump of diverse ethnic groups together to form an entity called Nigeria which was non-existent in pre-colonial era.This position has always been a point of discordant arguments among Nigerians because the position implies that Nigeria as a geopolitical entity is a mistake. This has also given rise to a lot of un-resolvable questions and confusion among scholars especially in categorizing the so-called major or minor ethnic groups in Nigeria. Ezeh further exposes more of these complexities in classifying the people of Nigeria by posing vital questions such as: 
Should we classify the Ekoi of the southeast as fourteen different but related groups or see them as only one group? Are we treat the Itsekiri as a subgroup of the Yoruba following Talbot (1926:60) or have them as an ethnic group on their own? In the north are the chomo-karim, Jiru, Kpan and Jukun the same group or are they distinct ethnic groups? Are the Izzi, Ikwere and the Kwale distinct ethnic groups or are they Igbo? (Ezeh 2002, p. 103).

Similarly, Eghafona \& Dokpesi, (2012); Ajala\&Aremu, (2012); Amzat \& Muhammad-Baba, (2012) employ a classificatory approach based on the type of environment where different Nigerian ethnic groups are located. This is because "climate and vegetations are important factors that shape cultural groupings in West Africa and they determine the type and level of economic, technological and political activities and even access to resources" (Ajala \& Aremu, 2012, p.51). They environmentally classify Nigerian peoples into three namely: the people of the mangroves (coastal dwellers in the south-south involving people of Bayelsa, Edo, Akwa-Ibom, Delta-cross- Oron, Ibibio, Ogoni, Ikwere, Ndoni, Egbema, Ijaw (izon). The people of the forest region believed to be of Bantu origin being speakers of the kwa sub-division of the Niger-Kordofanian languages - Igbos, Yorubas, Igala, Tiv, Ekoi, Uhorobo, Anang, Efik, Kalabari); and the people of the savannah (Hausa-Fulani). However, Onwuka (2002:3-4) employs a zonal classificatory approach. He broadly divided the Nigerian people into two zones namely:

(a) The people of the forest zone

(b) The people of the savannah or grass land zone.

Each of these zones was further sub divided into two namely: The forest zone includes:

(a) Peoples of the western forest belt whose major ethnic groups are the Yoruba, Edo, Urhobo, Itshekiri, etc. 
(b) People of the eastern forest belt: are Igbo, Efik, Ijaw, Ibibio, Ogoni, ogoja, etc.

While the grassland or savannah zones are:

(a) People of the middle belt: They are the Tiv, Nupe, Igbira, Jukun, Idoma, Igala, etc.

(b) Peoples of the far North belt: They are the Hausa, Fulani and Kanuri etc.

On the other hand Aremu (2008) prefers a lumping approach, by just listing the numerous ethnic groups as Yoruba, Igbo, Ijaw (Izon), Kanuri, Fulani, Tiv, Nupe, Hausa, Jukun, gwari, Itsekiri, Ogoni etc. without recourse to their geographical locations or any classificatory criteria. Ezeh (2002: 104-114) however uses a linguistic and geographic approach in categorizing the people of Nigeria namely:

1. Groups southeast of the Niger: Igbo, Adoni, Anyang, Bekwara, Boki, Degema, Efik, Ekoi, Epie-Atisa, GOkana, Ibibio, Ijaw (Izon), Kalakan, Ubembe, Ngene, Okirika, Ogoni, Orring, Yale, Yako

2. Group southwest of River Niger: Yoruba, Edo, Egba, Egun, Etasaka, Ijaw, Haje, Ishan, Isoko, Itsekiri, Urhobo Yoruba

3. Groups in the North: Hausa, Abon, Alago, Anagura, Angas, Arum, Ateni, Bambuka, Bandawa, Bassa, Bali Biroom, Chawai, Chomoakarin, Fulani, Ganagana, Idoma, Igala, Igbira, Jukun, Kpan, Kpansham, etc.

It important to note that these arbitrary classifications of Nigerians by scholars have political, cultural and even religious undertones which maybe potential source of inter-cultural/ethnic rivalry. Contrary to the Eurocentric assertions by early European explorers, travelers and arm chair anthropologists, that Africans and by extension Nigerians had no history, and culture, but are primitive, 
lazy, cursed, inherently evil, heathen, corrupt, beyond redemption, doomed and third world (Rodney, 1972; Basden 1982; Seligman, 1930). Through detailed ethnography, scientific research and archaeological excavations and findings has revealed that Africans and indeed Nigerians have rich cultures, earliest evidence of humans, architecture, and technology. Thus, Africa remains the cradle of humanity and cultures. This reflects a true identity of Africans who are hardworking, intelligent endowed with cherished cultural values and other unique heritages to preserve.This is manifested in numerous antiquities and finds from some remarkable culture areas in Nigeria such as Nok in Plateau Jos dated to $\left(5^{\text {th }} \mathrm{BC}\right)$, Daima North-western Borno south of lake Chad, Igbo-Ukwu in Anambra state $\left(9^{\text {th }} A D\right)$, Ife $\left(12^{\text {th }}-14^{\text {th }}\right.$ century AD), Benin $\left(13^{\text {th }}-15^{\text {th }}\right.$ century AD), ( Fasuyi, 1973; Ugboaja, 2010; Aremu, 2008; Eluyemi, 2002).

\section{Some Cultural Heritages of Nigeria}

Marguba in Aremu (2001:14) identifies the following cultures of Nigerian people which have been described as most memorable cultural destinations in Nigeria today. They include:

\section{Northern Nigeria}

1. Annual Argungu festivals in Kebbi state.

2. Annual Sallah Durbar in Katsina State

3. Gidan Hausa in Kano state

4. Farribachama Annual festival of Adamawa state

\section{Southern Nigeria}

1. Eyo masquerade of Lagos state

2. The Bakor Yam festival in Cross River state and others

3. Osun - Oshogbo festival in Osun state

4. Imo Awka masquerade ceremony in Awka, Anambra state.

Apart from the above, Nigerian societies are known for their unique new yam festivals celebrated in almost all communities in Nigeria. New yam festivals depict the agricultural prowess of 
Nigerians and their cultural value for hard work. Nigerians practice unique traditional marriage ceremonies such as the Igba-Nkwu among the Igbo and fattening festivals that help to educate young maidens with virtues and chastity for womanhood. Other Nigerian indigenous festivals that need to be preserved are: Eyo festival in Lagos, Lagos state, Fattening festival in Calabar, Cross River State. Pategi Regatta in Niger State, Moremi Festival at offa, Awon mass wedding at Shao in Kwara State, Epa festival at Obo Aiyegunle Ilorin, Agemo festival Ijebu Ode, Igogo festival at Owo in Ondo state, Boat Regatta in Rivers state, Epe Boat Regatta (Aremu, 2008).

Other Nigerian cultural heritages were the blacksmithing industry, brass-casting, bronze works and metal-working industries practiced across Nigeria, terracotta; wood carvers constructed beautiful stools and doors, engravings on walls and rocks etc. All these skills which served as good entrepreneurial and income yielding jobs have been abandoned for foreign ones in the quest for civilization (Anigbogu \& Onyima, 2013). For instance, Aremu, (2008) reports that after mining in traditional metal-working industries, the spongy mass of metallic iron known as the bloom is often sold to blacksmiths with which they fabricate several objects ranging from farm implements, hunting and fishing materials, palm wine tapping tools, weaving implements, household utensils, wood carving tools, ceremonial staff, military weapons, political royal swords, seats and scepter among others. This implies that the blacksmithing industry permeated most sectors of the society and as such its relevance and significance to pre-colonial Nigerians was not in doubt. It is also evident that this local industry created an avenue for employment and entrepreneurship beginning from the miners, to blacksmiths, distributors and even to users of products from the blacksmithing industry (Anigbogu \& Onyima, 2013). Considering the avalanche of benefits that could be derived from Nigerian cultural heritages, there is need for a clarion call to consciously preserve Nigerian heritages in spite of the daunting challenges facing its preservation. 


\section{Challenges: Impact of Ignorance, Conflicts, Change, Globalization and Development in the Preservation of Nigerian Cultural Heritages}

Nigerian cultural heritages are faced with a lot of challenges such as the influence of modernization, Christianity, commerce, civilization, change, development, looting, and antiquarians, among others. Apart from smuggling, theft, vandalism and looting of museums, another most threatening challenge facing Nigerian cultural heritage is religious dogmatism and iconoclasm. Eluyemi (2002) refers to them as die-hard suffering from colonial hangover; they are the religious zealots who burn cultural objects in the name of deliverance. Apart from human activities, in West Africa, the soils are generally acidic and the vagaries of weather as well as the destructive nature of termites militate against good preservation of cultural heritages (Ogundele, 2000). In spite of the above, the National Antiquities Commission (NAC) now National Commission for Museums and Monuments (NCMM) has taken bold steps in preserving these threatened heritages. The commission is responsible for the establishment and maintenance of museums and for discovery of heritage sites, ensures the preservation and study of traditional arts and culture. It also has powers to schedule monuments and antiquities, and to control archaeological excavations and the export of antiquities (Fasuyi, 1973). But the efforts by NCMM have often been stalled by some challenges ranging from low subventions and funding from government to carry out their statutory responsibilities.

Other challenges are some government developmental projects which destroy cultural heritages, conflicts and social change. Social change implies an alteration, modification or shift in behavior, attitude, social institutions and social structure. Most Nigerian social institutions and structures such a family, marriage and kinship systems are threatened by the wave of modernization, technological developments and globalization. For instance, the value system has gradually been eroded as issues like respect for elders, chastity, integrity and morality are considered archaic, while wrong values like disrespect, disobedience, nudity, fraud, 
kidnapping, corruption are entrenched in the society. This has been traced to the failure of the family system. Parents in their quest for wealth and materialism abandoned their primary responsibility of inculcating right moral values into their children through proper parental training. This affects the society in the long run negatively by leading to chaos and conflict.

Conflict is a situation of misunderstanding or disagreement between two or more persons. The various natural and cultural heritages in Nigeria such as monument, museums, game reserves, wild life sanctuaries and national parks are the most affected as they are targets for destruction during conflicts. Developmental projects like road constructions, buildings, and large-scale agriculture destroys cultural heritages, artifacts, and historical relics. Most times construction engineers do not embark on cultural or environmental impact assessment (EIA) before carrying out any construction. We must therefore note that the past is the key to the present, as anyone who does not know where he is coming from, might not know where he is going in future. Nigerians must therefore be perspicacious and pragmatic in the way they execute developmental projects and ensure there is peace and stability to ensure sustainable preservation of our cultural and natural heritages.

\section{Prospects: Economic, Tourism \& Development Potentials of Nigerian Cultural Heritages}

Nigeria stands to benefit a lot if her cultural heritages are adequately preserved. It has great potentials of boosting the country's economy through tourism. When cultural heritages are properly preserved and advertized through the print and electronic media, they stand a chance of attracting tourists from the nooks and crannies of the world. This would be a plus to national revenue and GDP, which will in turn provide more funds for the development of the country. Nigerian cultural heritages also are capable of promoting mutual understanding and respect among Nigerians. For instance, when people attend state or national cultural festivals, they will learn to 
appreciate the various cultures exhibited by people in Nigeria and this will engender unity in diversity.

Museums could contribute to Nigerians' appreciation of aesthetics, relaxation, and leisure, which could go a long way in dousing tensions and high blood pressures. Some non-material cultural heritages such as values of respect, integrity, and dignity of labour, will re-orientate Nigerians from materialism to appreciating appropriate morally right pursuits and endeavors. All these will culminate into a better Nigeria.

\section{Conclusion}

According to Fasuyi (1973), as at 1970 Nigeria had no specific written document known as Nigerian national cultural policy, the federal government inherited and continued the colonial administration policy on antiquities. This assertion has long changed, as a cultural policy for Nigerian was approved and launched in 1988 (Lo-Bamijoko, 2009). This cultural policy is anchored on the following;

(a) Preservation of culture

(b) Promotion of culture

(c) Presentation of culture

(d) Establishment of administrative structure and provision of funds for its implementation.

This paper has therefore focused on the first part of this policy by conceptualizing Nigerian cultural heritage, narrating the historical dimensions and efforts by Nigerians and the Nigerian government towards preservation, challenges and prospects, if myriads of the Nigerian cultural heritages are preserved.We therefore recommend the following; state festivals of arts and culture should be revived as was done previously. It should begin at the local government levels, winners should be sent to state festivals and finally to federal festivals of arts and culture competitions. By so doing the basic essentials and appreciation of Nigerian cultural heritages will be inculcated into younger generations. Media coverage of these cultural festivals would also broadcast the nation's cultural heritages 
to the wider audience/world. We concur to the following solutions identified by Eluyemi (2002) to the challenges confronting Nigerian cultural heritages namely, public enlightenment, funding, sponsoring archaeological excavations and research, provision of holistic security in museums among others. Proper reorientation of the police and collaboration with international police (INTERPOL) and with UNESCO is also recommended. Cultural resource managers/officers and personnel who are often collaborators with traffickers should be well remunerated, installation of surveillance cameras, proper documentation of artifacts, among others

*Blessing Nonye Onyima, Department of Sociology \& Anthropology, Faculty of Social Sciences, Nnamdi Azikiwe University Awka, Nigeria.Nonyelin2003@yahoo.com Onyima.blessing@gmail.com 


\section{References}

Andah, B. W., Okpoko, A. I., \& Folorunso, C. A. (Eds.) (1993).Some Nigerian Peoples. Special Book Issue, West African Journal of Archaeology. Ibadan, Demos Printers.

Anigbogu, K.C. \& Onyima, B.N. (2013). New Technology and Challenges of the Blacksmithing Industry In Awka: Implication For Entrepreneurship Development. African journal of microfinance and enterprise development, Vol 3(1):46-56.

Aremu, D. A. (Ed.) (2008). Preservation of Land, Culture \& Wildlife for the Development of Ecotourism in Africa. Ibadan, Spectrum Books Limited.

Basden, G. T. (1982). Among the Ibos of Nigeria. Lagos University Publishing Co.

Duke, O. (2008). Nigerian Ecotourism: An Overview. In D.A. Aremu, (Ed.) Preservation of Land, Culture \& Wildlife for the Development of Ecotourism in Africa. Ibadan, Spectrum Books Limited.

Eluyemi, O. (2002). The Preservation of Nigerian Cultural Heritage: Challenges \& Prospects. Fourth BasseyWaiAndah Memorial Lecture. Ibadan, Textflow Limited.

Ezeh, P.J. (2002). Inventory of Nigerian ethnic Groups- some theoretical \& social issues. In J.O. Onwuka, (Ed.) Nigerian Peoples and cultures: Historical \& Socio-structural Perspectives (pp. 100-117). Enugu Nigeria, Echris \& Company.

Fasuyi, T. A. (1973). Cultural policy in Nigeria: Studies \& Documents on cultural policies. Paris, UNESCO.

Lo-Bamijoko, J. N. (2009).The Nigerian music directory. http://musicinnigeria.blogspot.com/2009/05/nigerian-musicdirectory-compiledand.html.

Mathaias, A. B. \& David, M. (2014). Irumgbede: An Idigenous educational institution. In Ezeweke, E. O. (Ed.) African traditional religion philosophy \& sustainable Development. Jos, Fab Anieh Nig. Ltd. 
Nnonyelu, Au. N. (2009). Sociological Insights. Ibadan, Spectrum Books Limited.

Ogundele, S. O (2000). Fundamentals of archaeology: An introduction. Ibadan, Ejimasons Nigeria Enterprises.

Ogundele, S. O. (2014). Understanding Contemporary Archaeology. Ibadan, John Archers Publishers Limited.

Onwuka, J.O. (Ed.) (2002). Nigerian Peoples and cultures: Historical \& Socio-structural Perspectives. Enugu Nigeria, Echris\& Company.

Okpoko, A. I. (2011). Fundamentals of museum practice. Nsukka, University of Nigeria Press Ltd.

Rodney, W. (1972).How Europe underdeveloped Africa. Lagos, Panaf Publishing.

Seligman, C. G. (1930). Races of Africa. London Thornton Butterworth, Ltd.

Sowunmi, M. A. (2008). Tourism and security: facing the challenges. In D.A. Aremu, (Ed.) Preservation of Land, Culture \& Wildlife for the Development of Ecotourism in Africa. Ibadan, Spectrum Books Limited. 